\title{
Evaluation of natural additives for warm asphalt mix
}

\section{Evaluación de aditivos naturales para las mezclas asfálticas semicalientes}

Rosa Herrera de la Rosa (Main and Corresponding Autor)

Centro de Investigación y Desarrollo de la Construcción (CIDC).

Calle Línea No 810 esq. Carretera de Casablanca, Casablanca, Municipio Regla, Provincia La Habana (Cuba)

rosita@ctdmc.co.cu

\section{Anadelys Alonso Aenlle}

Universidad Tecnológica de La Habana José Antonio Echeverría (UTH).

Calle 114 y avenida 127, Municipio Marianao, Provincia La Habana (Cuba)

anadelys@civil.cujae.edu.cu

\section{Nelson Villegas Muñoz}

Centro de Investigación y Desarrollo de la Construcción (CIDC).

Calle Línea No 810 esq. Carretera de Casablanca, Casablanca, Municipio Regla, Provincia La Habana (Cuba)

nelson@ctdmc.co.cu

Manuscript Code: 1071

Date of Acceptance/Reception: 06.08.2018/30.01.2018

DOI: 10.7764/RDLC.17.2.330

\begin{abstract}
Asphalt professionals in Cuba, taking as a line of work the sustainability of pavements, are involved in the methods for obtaining warm asphalt mixtures, as a technology to achieve construction efficiency, conservation of resources and the environment without affecting the mechanical performance of hot asphalt mixes. On this basis, two fundamental lines have been investigated to obtain this type of mixtures, using natural resources of existence in the country: the natural zeolites of the Tasajera deposit and the sugar cane wax. The work exposes the availability of resources, as well as the main results derived from the researches carried out. The temperature reductions obtained from experimental research using both additions of natural origin is between $20-30^{\circ} \mathrm{C}$, which allows sustainable results in the production of asphalt mixtures.
\end{abstract}

Key words: Warm asphalt mixtures, modified asphalt, asphalt mixes, cane wax, zeolite.

\section{Resumen}

Los profesionales del asfalto en Cuba, tomando como línea de trabajo la sostenibilidad de los pavimentos, se encuentran involucrados en los métodos para la obtención de las mezclas tibias o semicalientes, como tecnología para lograr eficacia de construcción, la conservación de los recursos y el medio ambiente, sin que se afecten las prestaciones mecánicas de las mezclas en caliente. Sobre esta base se han investigado dos líneas fundamentales para la obtención de este tipo de mezclas, empleando recursos naturales de existencia en el país: las zeolitas naturales del yacimiento Tasajera y la cera cruda procedente de la caña de azúcar. El trabajo expone la disponibilidad de los recursos, así como los resultados principales derivados de las investigaciones realizadas. Las reducciones de temperatura obtenidas de la investigación experimental empleando ambas adiciones de origen natural se encuentra entre $20-30^{\circ} \mathrm{C}$, lo que permite resultados sostenibles en la producción de mezclas asfálticas.

Palabras clave: Mezclas tibias, mezclas semicalientes, asfalto modificado, mezclas asfálticas, cera de caña, zeolita.

\section{Introduction and description of the problem}

The main researches in which asphalt professionals are immersed in the latest years are aimed at the development of techniques that will help answering our society's current concern regarding our environmental and energy aspects, working on the basis of sustainability of the pavements.

Thus, the concepts of warm or semi-hot asphalt mixes (Warm Asphalt Mixes) (Enrobéstièdes) arise in which the manufacturing and execution takes place 30 to $40^{\circ} \mathrm{C}$ below the conventional hot mixes (del Val, 2009).

This temperature reduction obtained from the manufacture of warm asphalt mixtures is highly desirable for several environmental reasons, among the most important, the smoke and emissions reductions, as well as the energy savings (Agnusdei, 2009).

According to studies carried out, the reduction in fuel consumption is estimated between $10-35 \%$ of diesel (Jenkins, 2000) and a reduction in emissions of smoke between 30-50\% (Gil et al., 2009). 
Obtaining this type of technology of warm asphalt mixtures, can be classified into two large groups: Those that use water and those that use an organic additive or wax.

Processes that introduce small amounts of water into the hot asphalt, via a nozzle that injects water under pressure, or a hydrophilic material such as zeolite, or with a wet aggregate, in small amounts (approximately $2 \%$ ), into the hot asphalt, producing the expansion of the asphalt, and hence increasing its volume about 10-20 times. When the water enters in contact with the hot asphalt it turns into steam producing asphalt foam, which is then used to easily wrap the aggregates allowing the reduction of the conventional temperatures used (Gutierrez \& Valenzuela, 2009; Zaumanis, 2010).

Processes using organic additives, for example, Fischer-Tropsch waxes, Montana waxes, or Fatty Acid Amides, produce a decrease in the viscosity of the asphalt above the melting point of the wax. The type of wax must be carefully selected so that (Prowell, 2007):

- Its melting point is higher than the expected service temperatures, otherwise permanent deformations may occur.

- To minimize the brittleness of the asphalt at low temperatures.

Asphalt professionals in Cuba, following the line of international research, have developed the studies of warm mixtures with the use of zeolite, from Tasajera's deposit, as the foaming process of the asphalt from a hydrophilic material and the warm mixtures from adding the raw wax obtained from the sugar cane, as an additive to modify the viscosity of the asphalt.

The objectives of the study were: evaluate different sources of natural Cuban additives and obtain energy savings and environmental benefit, from the reduction of manufacturing temperatures and placement of conventional hot mixes without affecting the mechanical performance of them.

Materials and methods

\section{Natural zeolites}

Zeolites have been known since 1750 and have been found in rocks that are diverse in age, lithology and geological foundation (Romero, 1979).

In Cuba, 4 types of zeolites have been identified: heulandite, clinoptilolite, mordenite and analcita. These have been located in the volcanic-sedimentary formations of the Upper Cretaceous in the provinces of Las Villas and Camagüey and the Paleocene-Eocene in the Eastern Province mainly, although the deposits that have minerals of the zeolite type are located in almost all of our national territory (Romero, 1979). These can be exploited in the open and cost less than limestone (CTDMC, 1991).

Natural zeolites have properties that allow their application in the most dissimilar branches of the economy, mainly in many areas of industrial technology, agricultural production, construction, public health, etc.

Its molecular geometry contains pores (usually filled with water) that are linked together forming channels and cavities, which allow them to lose and gain water reversibly. This property is precisely what is sought for its use in warm asphalt mixtures.

The contents of zeolite mineral in some of these deposits have been calculated and associated with the dehydration of the zeolite structure and the loss of the interlaminar water of montmorillonite, present in the samples (Gener, 1979; Gener \& Alonso, 2002).

Table 1. Content of mineral zeolite in different deposits of the national territory. Source: Gener (1979.)

\begin{tabular}{|c|c|c|c|c|c|c|c|}
\hline \multirow{3}{*}{$\begin{array}{l}\text { Zeolite } \\
\text { (heulandite } \\
\text { type) }\end{array}$} & & & & & & & San \\
\hline & $\begin{array}{l}\text { Carolina, } \\
\text { Cienfuegos }\end{array}$ & $\begin{array}{l}\text { Palmarito, } \\
\text { S. Cuba }\end{array}$ & $\begin{array}{c}\text { Tasajera, } \\
\text { V.Clara }\end{array}$ & $\begin{array}{l}\text { Piojillo, } \\
\text { V.Clara }\end{array}$ & $\begin{array}{c}\text { Sabaneta, } \\
\text { Guantánamo }\end{array}$ & $\begin{array}{c}\text { San Andrés, } \\
\text { Holguín }\end{array}$ & $\begin{array}{l}\text { Benito, } \\
\text { S.Cuba }\end{array}$ \\
\hline & $\leq 27$ & $\leq 35$ & $\leq 38-70$ & $\leq 46$ & - & $\leq 40-70$ & - \\
\hline
\end{tabular}


Considering these results, it can be expected that these deposits of natural zeolites release approximately more than $20 \%$ of water in the form of vapor when added to hot aggregates just before the wrapping process to produce the "foaming" effect, similar to what happens with the synthetic zeolites that are used in the market for warm asphalt mixtures.

Currently, six large deposits have benefit plants installed, but only the plants of San Andrés in Holguín and Tasajeras in Villa Clara (Rosell, 2010) are in operation and production.

The installed production capacity corresponds to 50,000 tons per plant per year, although from the 0-0.8 mm fraction, it is estimated that only 6000 tons per plant can be produced per year.

The main commercial products of the zeolite belonging to Geominera Centro Company are shown in the following Table.

\begin{tabular}{lc}
\multicolumn{2}{c}{ Table 2. Marketed products from Zeolite deposits. Source: Geominera (2010). } \\
\hline & \\
Commercial products & Nominal Dimensions (mm) \\
\hline Zoad secado a granel & $0-0.8$ \\
Zoad secado envasado & \\
Litosand secado & $0.4-3$ \\
Fertisol secado granel & $1-3$ \\
Fertisol secado envasado & $3-8$ \\
Zook secado granel & $3-8$ \\
Zook secado envasado & $3-8$ \\
Zook secado big bags & $3-8$ \\
Zeotec & $12-25$ \\
Polvo de ciclones & $\leq 0.074$ \\
\hline
\end{tabular}

The research to use of natural zeolites was developed by the UTH, as part of a doctoral thesis (Alonso, 2012). The experiments were conceived in three consecutive phases:

Phase 1) Comparison of mixtures manufactured with Tasajera's Zeolite and a synthetic zeolite that is commercialized in the world used for this type of mixtures;

Phase 2) Analysis of the most favorable granulometry to add Tasajra's natural Zeolite, for which three fractions of zeolite were studied:

- Filler or cyclone dust, with particle size less than $0.074 \mathrm{~mm}$.

- Fine sand, fraction 0-0.6 mm, commercially known as Zoad.

- Coarse sand, fraction 0-4 mm, commercially known as Litosand.

Phase 3) Influence of the amount of Tasajera's natural Zeolite added in the mixture, in the form of filler and sand (0-4 $\mathrm{mm})$.

The evaluation procedure developed included the Marshall method, the determination of the susceptibility to water and the dynamic modulus of rigidity in the mixture.

The design of the working temperatures was based on the reduction of the traditional temperatures of aggregate heating up to $135^{\circ} \mathrm{C}$, maintaining the heating temperature of the asphalt at $160^{\circ} \mathrm{C}$. This leads to reductions in the mixing and compaction temperatures of the mixture at 130 and $120^{\circ} \mathrm{C}$, respectively.

\section{Sugar cane wax}

In Cuba, cane wax is marketed mainly for the production of PPG (Policosanol) in the pharmaceutical industry.

There were eight raw cane wax extraction plants in the country, which currently require intensive repair and maintenance. As part of the wax program, an evaluation of the existing production plants was carried out, recommending keeping only 3 of the existing plants active, using the resources of the deactivated plants for the repair and recovery of the active plants (Herrera, 2010). 
The plants that would be kept active:

- Central Antonio Guiteras y Central Majibacoa from Las Tunas province.

- Central Cristino Naranjo from Holguín province.

Each plant could contribute between 4000 and 5000 tons of raw wax, that is, 40 to 50 times the quantities of crude wax to be refined for PPG.

This would allow a surplus that could be applied in the construction industry in proven applicability research that substitutes important imports; furthermore they develop Cuban construction industry's products, for example the water-repellent cement, IMPERCEL, the release agent for the prefabrication industry, CERAMOLD, as a curing product and obviously its use in the development of semi-hot mixtures.

On the other hand it is known that all the wax obtained is not suitable for the production of PPG. According to the results of the inspection carried out at the wax plants in July 2004, at least 200 tons of suitable refined wax and no less than 1200 tons of crude wax are available, which means that cane wax production is now paralyzed, since the stored lots allow a reserve of 20 years for PPG's production. The quantities of waxes produced are stored in these 3 facilities (Herrera, 2010).

The research with raw sugar cane wax addition, was developed in the CIDC, as part of a technological development research project of MICONS (Herrera, 2010). The experiments were conceived in three consecutive phases:

Phase 1) Determination of the optimum percentage of cane wax to be added to the asphalt:

- Several mixes are made using different addition ranging from 1 to $4 \%$.

Phase 2) Study the rheological behavior of modified asphalts with cane wax:

- Through the basic techniques of measuring asphalts' consistency: Penetration, softening temperature, ductility and thin film aging.

Phase 3) Determination of the temperature reductions by adding cane wax.

The general evaluation procedure developed included the measurement of Brookfield rotational viscosity, the evaluation of the short-term aging effect of the mixed asphalts with wax and Marshall's compaction methods. The experiment used an asphalt classified as AC-20.

\section{Results}

\section{Laboratory results of experimenting with natural zeolites from the Tasajera Deposit}

Tasajera's natural zeolite in its filler granulometry behaves in a similar way to the synthetic zeolite that is marketed for such purposes. Only slight increases in the voids content of the mixture stand out (Figure 1).

Figure 1. Comparison between Synthetic Zeolite and Tasajera's Natural Zeolite. Source: own elaboration. 


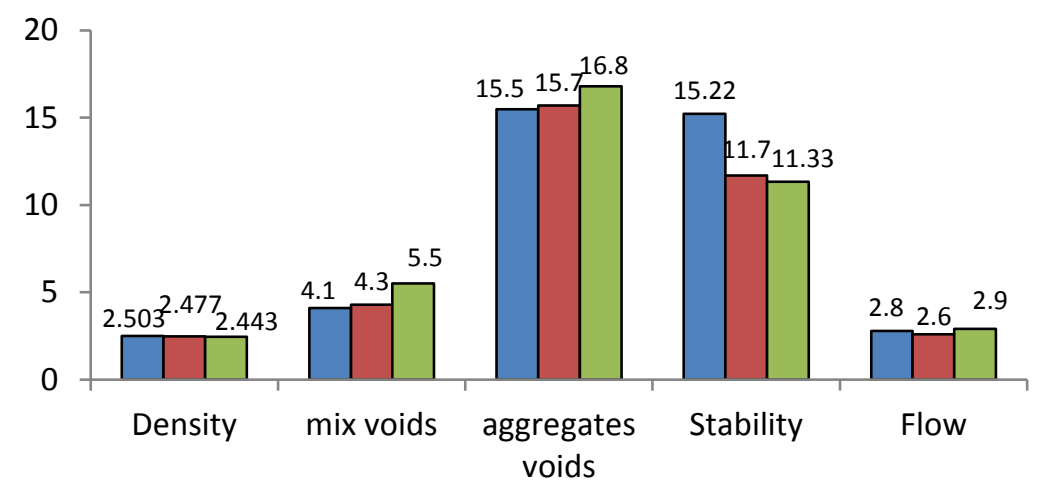

$\square$ Pattern $\square$ Zeo artificial $(0.3 \%) \quad \square$ Zeo Tasajera(0.3\%)

- In general, Tasajera's Natural Zeolite can be added to the mix in different granulometries, such as filler, fine or coarse sand, achieving the required stabilities for heavy traffic design conditions and rolling layer (Figure 2).

- It is emphasized that when used as fine sand $(0-0.8 \mathrm{~mm})$ there is no relevant difference to its granulometry as filler (less than $0.074 \mathrm{~mm}$ ), so its selection in one or the other fraction can be associated with the cost of the product.

- The increase in the void content of the mixture obtained when it is used in its coarse sand granulometry $(0-4 \mathrm{~mm})$ is highlighted, due to the low density of the zeolite.

- There must be good control of the content of zeolite that is added, while introducing water into the mixture, it may affect the adhesiveness of the binder with the aggregates. A substantial improvement is obtained when additions such as hydrated lime are used to improve the aspects related to the adhesiveness to the binder.

- The temperature reduction achieved is $30^{\circ} \mathrm{C}$ in relation to the manufacturing temperature of a hot mix.

Figure 2. Variation results in natural zeolite's granulometry. Source: own elaboration.

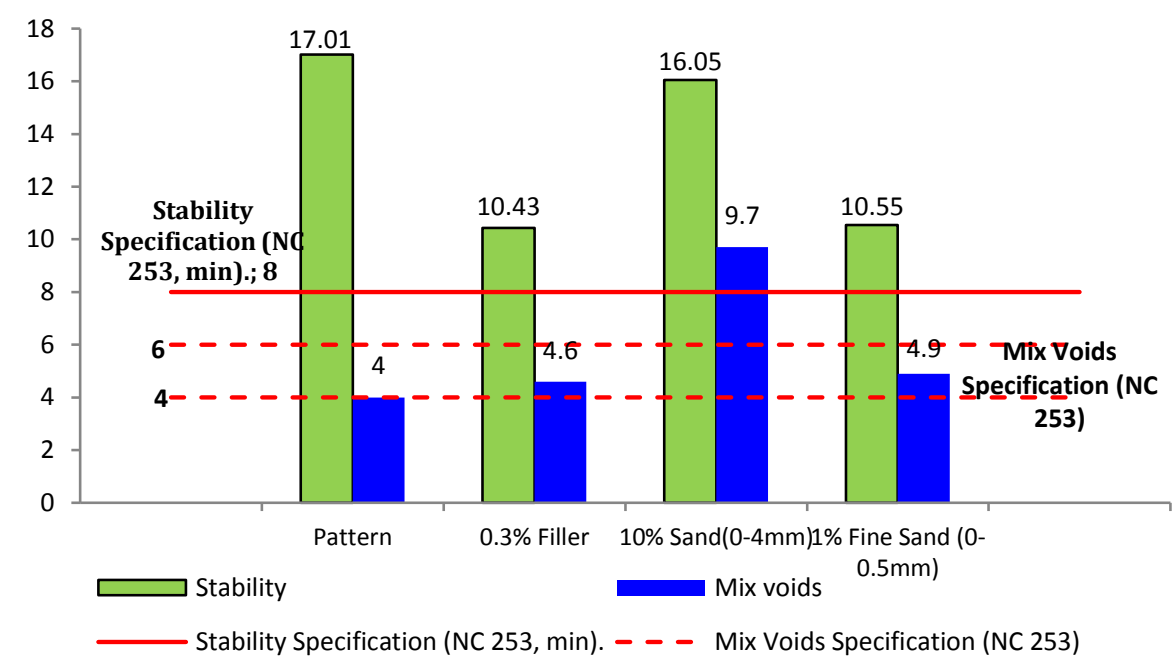

Laboratory results of experimenting with raw sugarcane wax addition

- The composition of the raw cane wax was $55 \%$ wax and $45 \%$ oils and resins. Its melting point is $77^{\circ} \mathrm{C}$, which facilitates its dissolution in the asphalt at working temperatures.

- A reduction between 9 and 7 degrees of temperature is obtained, for asphalts with 1 and $2 \%$ addition of cane wax respectively, according to the temperatures at which it can be mixed and compacted in an appropriate way, considering the recommendations of rotational viscosity established in the SUPERPAVE method (Figure 3).

- In relation to the consistency of the asphalts the addition of wax does not cause appreciable variations in the penetration and softening point values, however, it does produce a decrease in the asphalt's ductility, although without affecting the value required in the specifications (Figures 4,5 and 6 ).

- The optimum content of raw cane wax addition, according to the results of the viscosity measurements and rheological evaluation of the mixed asphalts, is estimated at $2 \%$ addition.

- The results obtained in the density measurements of Marshall probes indicate that a $20^{\circ} \mathrm{C}$ temperature reduction can be obtained with a $2 \%$ addition of raw cane wax. 


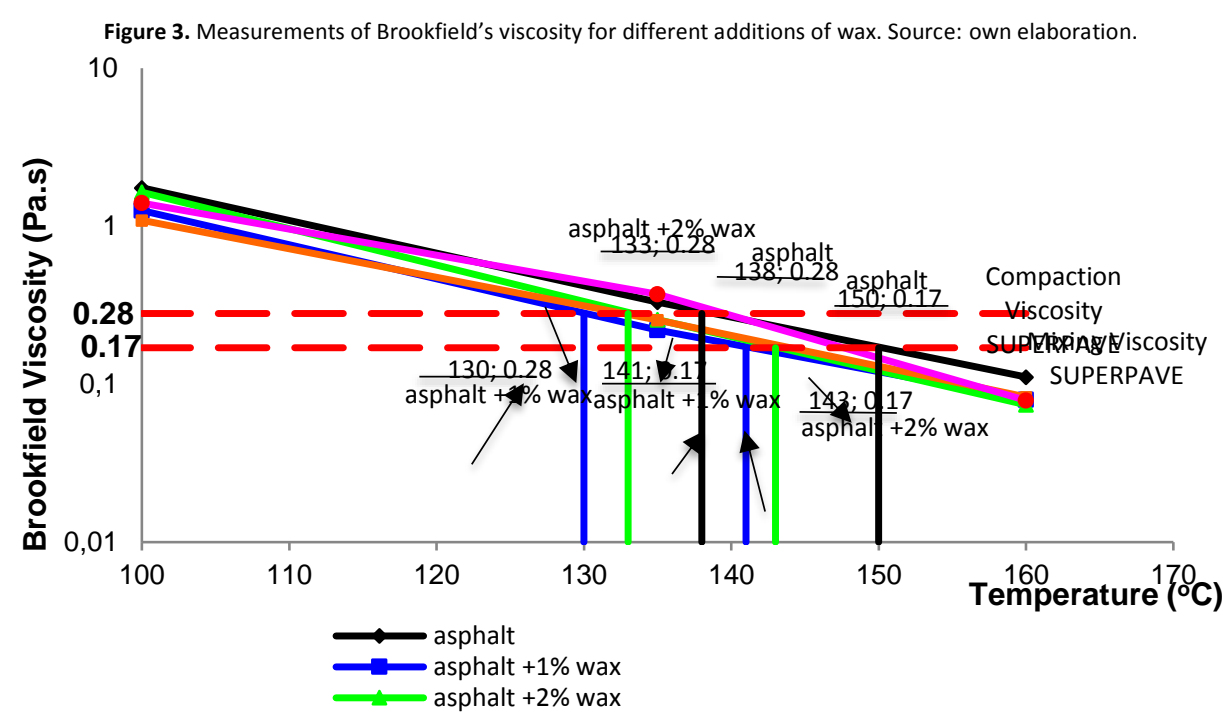

Figure 4. Results of penetration test of two asphalt samples with different addition contents, before and after aging. Source: own elaboration.

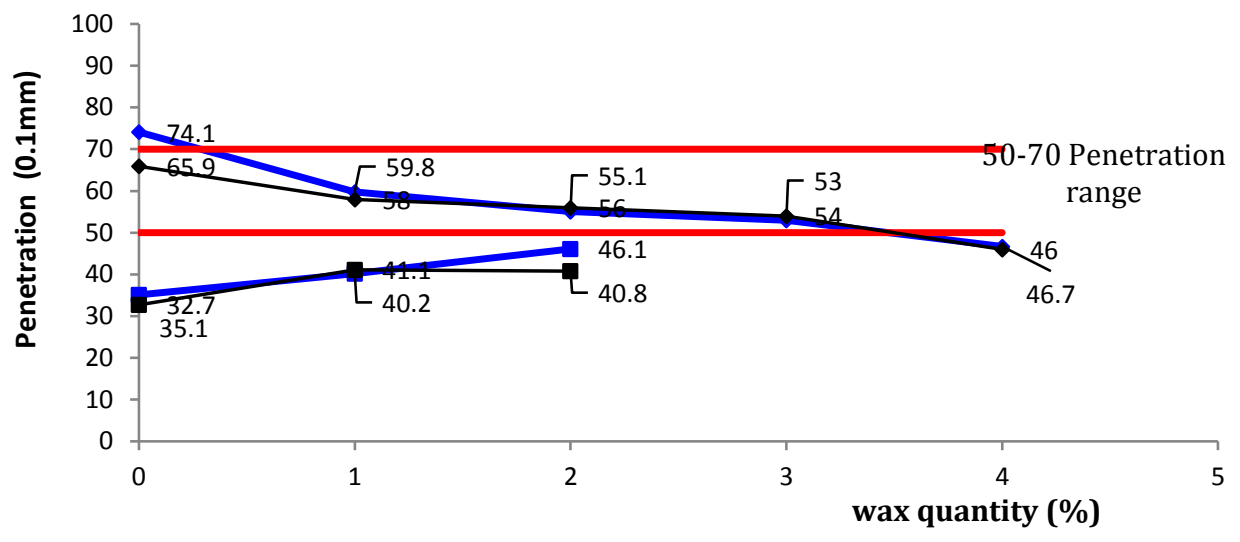

Test of virgin asphalt and additivated asphalt before TFOT aging (sample1)

-Test of virgin asphalt and additivated asphalt after TFOT aging (sample 1)

$\longrightarrow$ Test of virgin asphalt and additivated asphalt before TFOT aging (sample2)

$\longrightarrow$ Test of virgin asphalt and additivated asphalt after TFOT aging (sample 2)

Figure 5. Results of softening point test of two asphalt samples with different addition contents, before and after aging. Source: own elaboration.

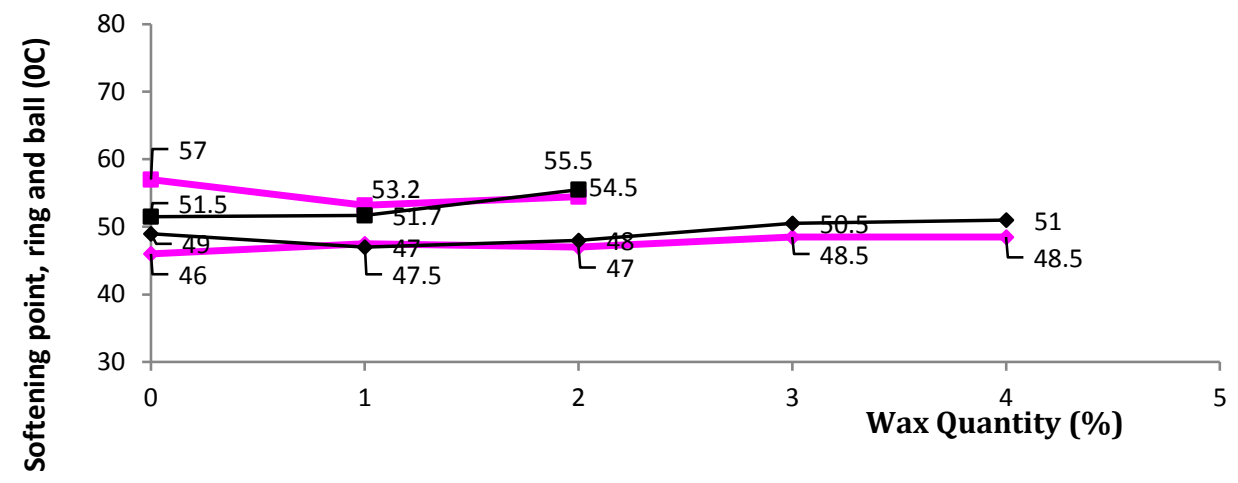

$\longrightarrow$ Test of virgin asphalt and additivated asphalt before TFOT aging (sample1)

- Test of virgin asphalt and additivated asphalt after TFOT aging (sample 1)

$\longrightarrow$ Test of virgin asphalt and additivated asphalt before TFOT aging (sample2)

$\rightarrow$ - Test of virgin asphalt and additivated asphalt before TFOT aging (sample2) 
Figure 6. Results of Ductility test of two asphalt samples with different addition contents, before and after aging. Source: own elaboration.

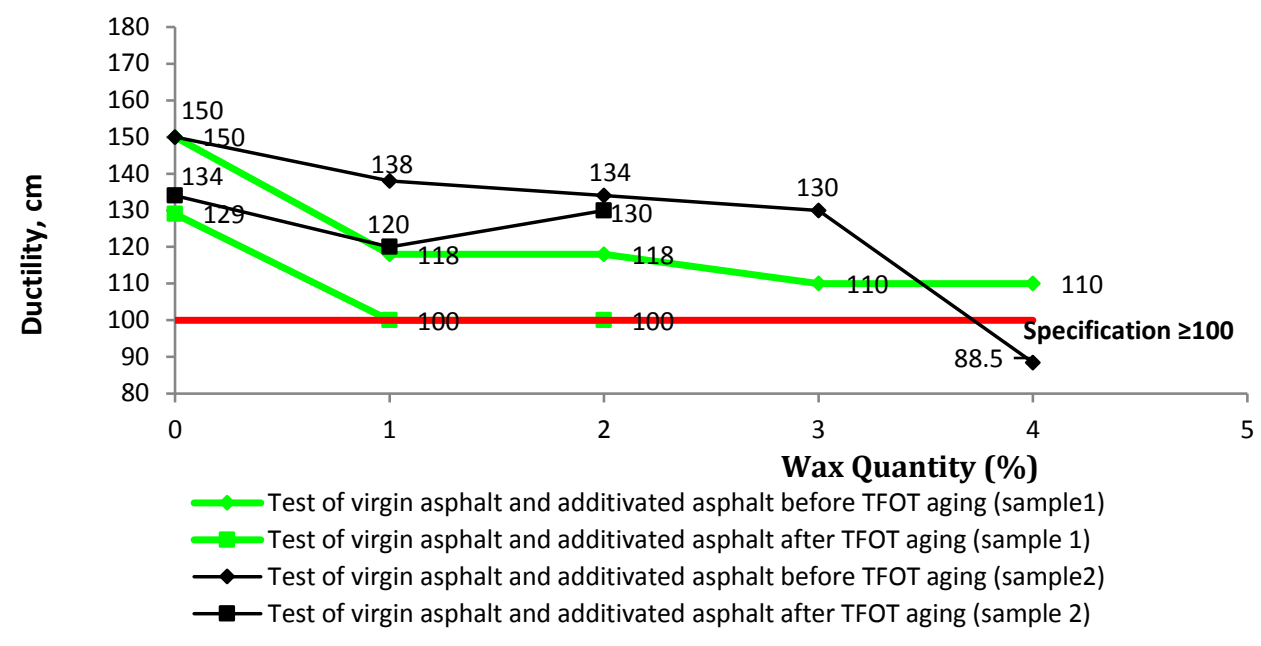

Conclusions

- The existence of natural resources in appreciable quantities in the country, such as zeolitized rocks and waxes from active plants such as sugarcane, represents a viable alternative to manufacture warm asphalt mix in Cuba, with sustainable results in the production of asphalt mixtures.

- The temperature reductions obtained by using natural additives are between 20 and $30^{\circ} \mathrm{C}$ and are estimated to produce an energy saving of 840,000 USD per year, which will decrease the emissions of $\mathrm{CO}_{2}$ by 5,000 tons to the atmosphere.

\section{References}

Agnusdei, J.O. (2009, noviembre). Innovaciones en asfaltos y conformidad ambiental. Documento presentado en la reunión del XV CILA. Lisboa, Portugal.

Alonso, A. (2012). Obtención a nivel de laboratorio de una mezcla asfáltica semicaliente a partir de la utilización de zeolita natural cubana del yacimiento de Tasajeras. (Tesis doctoral no publicada). Universidad tecnológica de La Habana José Antonio Echeverría. La Habana, Cuba.

CTDMC. (1991, octubre). Las zeolitas naturales en Cuba. (Informe técnico). Centro Técnico para el Desarrollo de los Materiales de Construcción. La Habana, Cuba.

del Val, M.A. (2009, noviembre). Asfalto para a Sustentabilidade dos Pavimentos. Misturas betuminosas semiquentes. Documento presentado en la reunión del XV CILA. Lisboa, Portugal.

Gener, M. (1979, diciembre). Composición mineralógica de puzolanas naturales cubanas. Boletín Centro de Investigación y Experimentación de la Construcción, (3), 7-30.

Gener, M. \& Alonso, J.M. (2002). Influencia de la composición mineralógica de puzolanas naturales en las propiedades de los cementos con adiciones. Materiales de Construcción, 52(267), 73-77.

Geominera. (2010, octubre). Información comercial de la Empresa Geominera Centro. Villa Clara, Cuba.

Gil, S., Amor, J.I., Felipo, J., Costa, A., Cortés, C., Páez, A., Valor \& Potti, J.J. (2009). Estudio de los aditivos que permiten reducir la viscosidad del ligante a elevadas temperaturas. Actas finales XV CILA, 185-194.

Gutiérrez, A. \& Valenzuela, L.T. (2009). Desarrollo de mezclas tibias en México. Actas finales XV CILA, 715-723.

Herrera, R. (2010). Evaluación de Aditivos para la Reducción de las Temperaturas de Fabricación y Colocación de las Mezclas Asfálticas en Caliente. (Inf. téc. No. 04.21.10). Centro de Investigación y Desarrollo de la Construcción de Cuba.

Jenkins. K, (2000). Mix Design Considerations for Cold and Half-Warm Bituminous Mixes with Emphasis on Foamed Bitumen. (Doctoral Dissertation, Stellenbosch University). Retrieved from http://www.warmmixasphalt.com/

Prowell, B. D. (2007). Warm mix asphalt. The International Tecnology Scanning Program. (Summary report). Retrieved from http://www.warmmixasphalt.com/

Romero. J.C, 1979. Zeolitas naturales, nuevo recurso mineral cubano. (Conferencia). Centro de Investigaciones Geológicas. La Habana, Cuba.

Rosell. M, 2010. Zeolita natural cubana del tipo clinoptilolita-heulandita como material cementicio suplementario en hormigones. (Tesis Doctoral no publicada). Universidad Central de las Villas Marta Abreu. Cuba

Zaumanis, M. (2010). Warm Mix Asphalt Investigation. (Master of Science Thesis). Technical University of Denmark. Department of Civil Engineering. 